\title{
PENERAPAN METODE FUZZY K-NEAREST NEIGHBOR (FK-NN) UNTUK MENENTUKAN PENYAKIT PADA TERNAK SAPI POTONG
}

\author{
Junandra H. Tomasoey ${ }^{1}$, Yohanis Malelak ${ }^{2}$ \\ Program Studi Teknik Informatika S1 STIKOM Uyelindo \\ Jl. Perintis Kemerdekaan No. 1- Kayu Putih, Kupang-NTT \\ Email:yohanismalelak@yahoo.com
}

\begin{abstract}
Cattle are one of the livestock commodities that are a mainstay as a source of protein. Animal is meat that is quite well known in the community. Decent meat taken from healthy livestock and free from diseases caused by diseases suffered by cattle must be handled seriously. Beef cattle breeders in East Nusa Tenggara, especially young cattle breeders, are hard to find by medical personnel such as compilation veterinarians to find sick cattle. On the other hand, the Livestock Service Office of NTT Province annually collects cattle disease data to draw conclusions about animal diseases in the regency / city in East Nusa Tenggara. Through data from the Kupang District Animal Husbandry Service, East Nusa Tenggara with data mining techniques can predict livestock disease using the Fuzzy K-Nearest Neighbor (FK-NN) algorithm. Fuzzy K-Nearest Neighbor (FK-NN) algorithm works by receiving input of diseases as input, then it will be processed with FK-NN algorithm and the results of processing become diagnoses of diseases suffered and therapeutic suggestions for diseases in beef cattle So it can increasing the yield of beef collected from beef cattle and minimizing the costs incurred by cattle farmers to care for infected livestock to consult with veterinarians.
\end{abstract}

Keywords: Beef Cattle Disease, Data Mining, Fuzzy K-Nearest Neighbor

\section{PENDAhuluan}

Sapi merupakan salah satu komoditi peternakan yang menjadi andalan sebagai sumber protein hewani berupa daging yang cukup familiar di masyarakat. Namun sampai dengan saat ini kebutuhan konsumsi daging sapi nasional masih belum tercukupi sehingga pemerintah melakukan impor daging sapi untuk memenuhi kebutuhan tersebut. (Priyanto, 2016).

Daging yang layak dikonsumsi berasal dari hewan ternak yang sehat. Hewan sehat adalah hewan yang tidak sakit dengan ciri-ciri bebas dari penyakit yang bersifat menular atau tidak menular, tidak mengandung bahan-bahan yang merugikan manusia sebagai konsumen, dan mampu berproduksi secara optimum (Astiti, 2010)

Penyakit pada ternak sapi potong dapat menimbulkan kerugian ekonomi yang cukup besar bagi peternak khususnya dan masyarakat luas pada umumnya. Panyakit-penyakit pada ternak sapi adalah sebagai berikut Septichaemia Epizooticae (Penyakit Ngorok), Antraks, Brucellosis, Para Turberculosis -
Jhone's Disease, T.B.C (Tuber Culosis), Fasciolosis,Mastitis, Tetanus, dan Rabies.

Peternak-peternak sapi potong di Nusa Tenggara Timur terutama peternak sapi muda terkadang sulit menemukan tenaga medis seperti dokter hewan ketika menemukan ternak sapi yang sakit. Jenis obat untuk suatu penyakit berbeda-beda sehingga pengobatan yang tepat dapat dilakukan apabila penyakit yang dialami dapat diidentifikasi dengan benar melalui gejala-gejala yang timbul dari penyakit tersebut.

Penyakit yang diderita pada hewan dari tahun ke tahun dikumpulkan menjadi data oleh Dinas Peternakan Provinsi NTT untuk dijadikan gambaran situasi penyakit hewan diwilayah Kabupaten/Kota di Nusa Tenggara Timur. Dengan data tersebut dapat diolah menjadi informasi lain yang lebih berguna dengan data mining.

Beberapa penelitian telah dilakukan untuk membantu menyelesaikan permasalahan dengan menggunakan Algoritma data mining. Sebagai contoh beberapa penelitian yang pernah dilakukan sebelumnya yaitu Sistem 
Pendukung Keputusan Diagnosis Penyakit Sapi Potong Menggunakan K- Nearest Neighbour (K- NN) (Kurnianingtyas, 2017), Penerapan Fuzzy K-Nearest Neighbor (FKNN) Dalam Menentukan Status Gizi Balita (Nugraha, 2017), Pengembangan Sistem Pakar Diagnosa Penyakit Sapi Potong Dengan Metode Fuzzy K-Nearest Neighbour (Tyas, 2015), Identifikasi Penyakit Tanaman Jarak Pagar Menggunakan Metode Fuzzy K-Nearest Neighbor (FK-NN) (Ompusunggu, 2017).

Berdasarkan uraian tersebut maka dalam penelitian ini akan diterapkan teknik Data mining dengan menggunakan algoritma FK$\mathrm{NN}$ untuk mengklasifikasikan jenis penyakit ternak sapi potong.

\section{METODE PENELITIAN}

Sistem yang akan dibuat merupakan sistem yang mengimplementasikan metode Fuzzy K-NearestNeighbor untuk mengidentifikasi penyakit ternak sapi potong. Sistem ini ditujukan untuk mengetahui kemampuan algoritma Fuzzy KNearestNeighbor untuk memprediksi penyakit yang di derita ternak sapi potong.

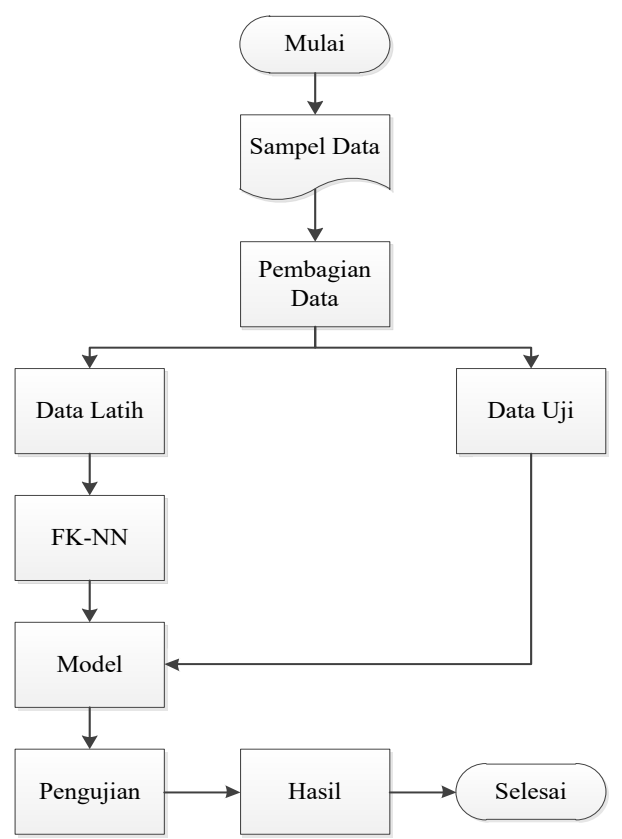

Gambar 1.Diagram alur Perancangan sistem

\section{Sampel Data}

Sampel data yang digunakan yaitu 67 data ternak sapi yang sakit dari tahun 2016 - 2018 di Kabupaten Kupang. Parameter yang digunakan pada sistem yaitu 9 jenis penyakit dengan 52 gejala penyakit.

\section{Pembagian Data}

Pembagian data menggunakan holdout validation, data secara acak dibagi menjadi dua buah bagian yang yaitu data latih dan data uji. Perbandingan yang digunakan yaitu 5:1 untuk data latih berbanding data uji.

3. Membangun Model Fuzzy KNearestNeighbor

Berdasarkan pembagian data pada Gambar 3.3. dilakukan pembangunan model dengan algoritma FK-NN yang ditunjukkan ke dalam Gambar 2.

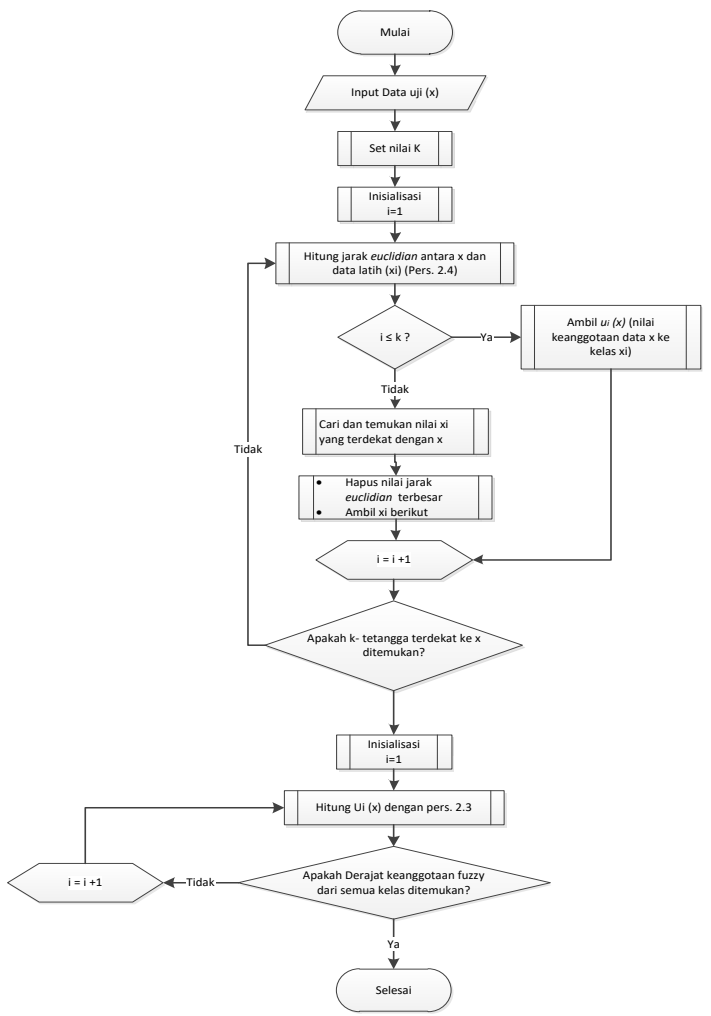

Gambar 2. Diagram alur Algoritma FK-NN

4. Pengujian

Pengukuran kinerja penelitian ini dilakukan dengan matriks konfusi (confusion matriks). dapat dilihat pada Tabel 1.

Tabel 1. Matriks konfusi

\begin{tabular}{|l|l|l|l|}
\hline \multicolumn{2}{|c|}{$f_{i j}$} & \multicolumn{2}{|c|}{$\begin{array}{l}\text { Kelas hasil prediksi } \\
(j)\end{array}$} \\
\cline { 3 - 4 } \multicolumn{2}{|c|}{} & $\begin{array}{l}\text { Kelas } \\
1\end{array}$ & $\begin{array}{l}\text { Kelas } \\
0\end{array}$ \\
\hline \multirow{3}{*}{$\begin{array}{l}\text { Kelas asli } \\
\text { (i) }\end{array}$} & $\begin{array}{l}\text { Kelas }= \\
1\end{array}$ & $\mathrm{f}_{11}$ & $\mathrm{f}_{10}$ \\
\cline { 2 - 4 } & $\begin{array}{l}\text { Kelas } \\
0\end{array}$ & $\mathrm{f}_{01}$ & $\mathrm{f}_{00}$ \\
\hline
\end{tabular}

Kuantitas matriks konfusi ditentukan menjadi menjadi 2 nilai yaitu akurasi dan laju error. 


$$
\text { Akurasi }=\frac{f_{11}+f_{00}}{f_{11}+f_{10}+f_{01}+f_{00}}
$$

Sedangkan untuk menghitung laju error (kesalahan prediksi) digunakan rumus:

$$
\text { Laju Error }=\frac{f_{10}+f_{01}}{f_{11}+f_{10}+f_{01}+f_{00}}
$$

\section{HASIL DAN PEMBAHASAN}

Tahap implementasi sistem merupakan tahap penerapan sistem agar dapat dioperasikan secara optimal sesuai kebutuhan. Implementasi antarmuka yang dibuat pada tahap perancangan, diimplementasikan menjadi bentuk GUI yang dibangun dengan menggunakan MATLAB R2017a.

\section{Tampilan Menu Utama}

Halaman menu utama Program perhitungan jenis penyakit sapi potong dengan metode Fuzzy K- NearestNeighbor adalah halaman yang pertama kali tampil. Halaman ini menyediakan navigasi untuk melakukan proses hitung yang dimulai dati input gejala sampe proses tampil data hasil hitung. Tampilan halaman utama dapat dilihat pada Gambar 3.

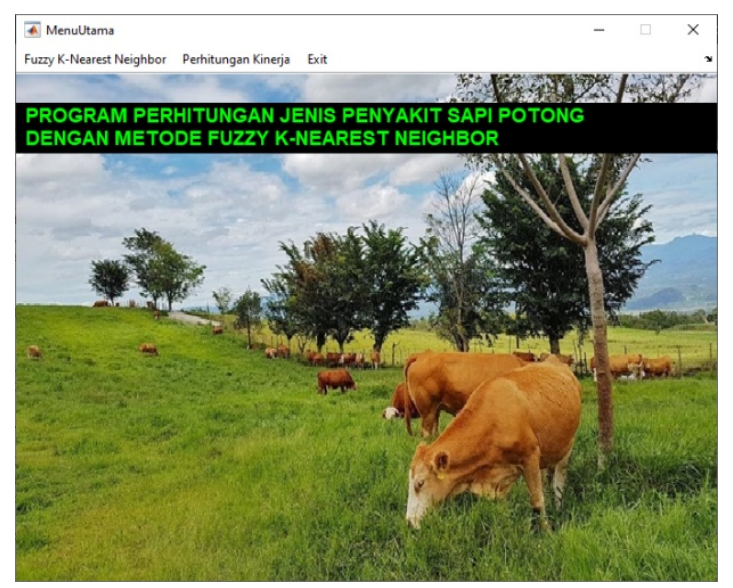

Gambar 3. Halaman Utama

\section{Tampilan Input Gejala}

Halaman input gejala Program perhitungan jenis penyakit sapi potong dengan metode Fuzzy K- NearestNeighbor adalah halaman untuk melakukan inputan gejala yang dialami data uji dengan memberikan bobot antar 0-1 sesuai dengan gejala yang dialami. Halaman ini menyediakan navigasi untuk halaman Data Latih dan Halaman Hitung. Tampilan halaman input gejala dapat dilihat pada Gambar 4.

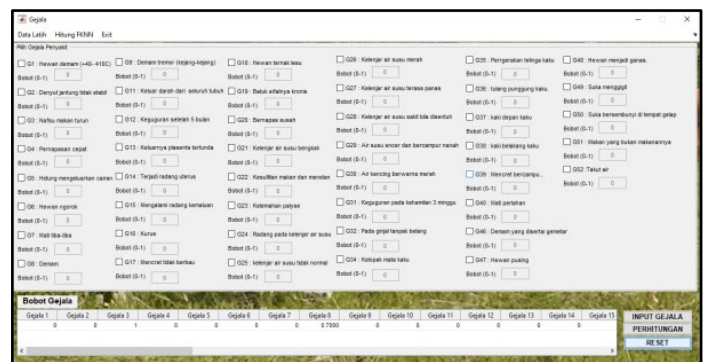

Gambar 4. Halaman Input Gejala

3. Tampilan Hitung FKNN

Halaman Hitung Program perhitungan jenis penyakit sapi potong dengan metode Fuzzy K-NearestNeighbor adalah halaman untuk melakukan proses perhitungan. Halaman ini menyediakan navigasi untuk halaman Data Latih dan Halaman Input Gejala. Tampilan halaman hitung dapat dilihat pada Gambar 5.

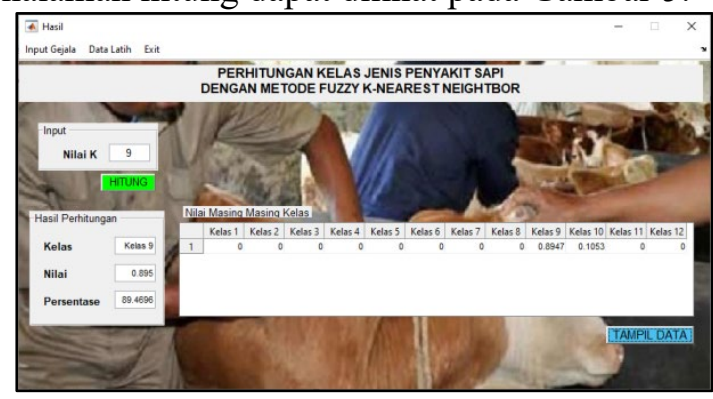

Gambar 5. Halaman Hitung

\section{Tampilan Data Latih}

Halaman Data Latih adalah halaman yang menampilkan bobot data latih yang tersimpan dalam datalatih.xlsx. Tampilan halaman data latih dapat dilihat pada Gambar 6 .

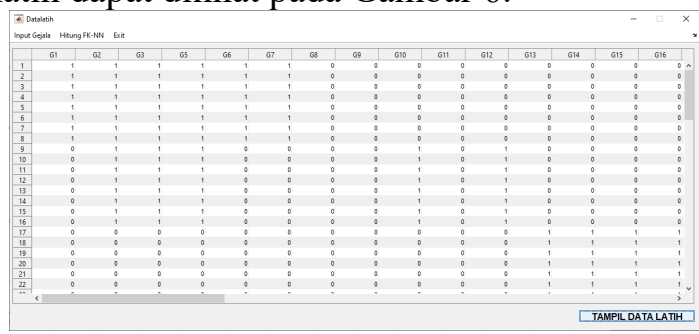

Gambar 6. Halaman Data Latih

\section{Tampilan HasilDiagnosa}

Halaman HasilDiagnosa adalah halaman yang menampilkan Hasil diagnose jenispenyakitsapipotongsesuaidenganhasipperh itungan.Dapat dilihat pada Gambar 7.

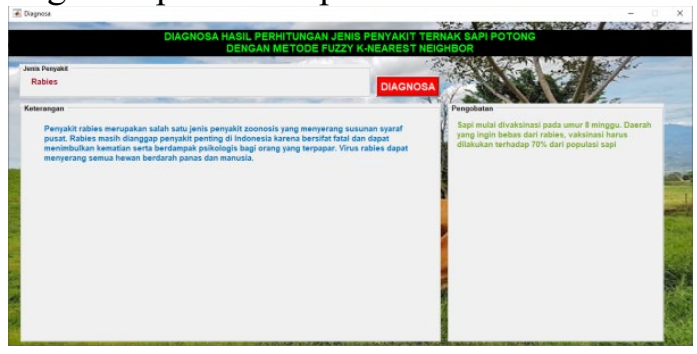

Gambar 7. Halaman Diagnosa 
6. Tampilan HasilDiagnosa

Halaman perhitungankinerja program penentuanjenispenyakitsapipotongdengan $F u z z$ $y$ K-NearestNeighaboradalahhalaman yang digunakanuntukmenghitungkinerja Fuzzy KNearestNeighabordalammemprediksi.Dapat dilihat pada Gambar 8.

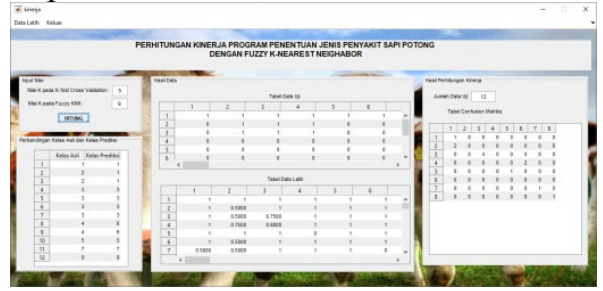

Gambar 8. Perhitungan Kinerja Program

a. PerhitunganFuzzy K-Nearest Neighbor

1. Perhitungan manual

Perhitungan manual dilakukan untuk melihat apakah hasil perhitungan aplikasi yang dibangun sudah sesuai dengan hasils ebenarnya, untuk itu diperlukan sebuah kasus ternak sapi potong yang sakit.

Seekor Ternak sapi potong merupakan sebuah data uju T117 memiliki penyakit dengan gejala sebagai berikut:

G48 : Hewan menjadi ganas $($ Bobot $=0,7)$

G49 : Suka menggigit dan meronta jika diikat

$($ Bobot $=1)$

G50 : Suka bersembunyi di tempat gelap

$($ Bobot $=1)$

G52 :Takut air. $($ Bobot $=1)$

Langkah pertama:

Menentukan jarak data uji $(x)$ dengan setiap data latih menggunakan Euclidan Distance dengan persamaan 2.3.

- $\operatorname{Jarak}_{(\mathrm{T} 118, \mathrm{~T} 1)}$

$$
\operatorname{jarak}_{(T 118, T 1)}=\left(\begin{array}{l}
|0-1|^{2}+|0-1|^{2}+|0-1|^{2}+|0-1|^{2}+|0-1|^{2}+|0-1|^{2}+ \\
|0-0|^{2}+|0-0|^{2}+|0-0|^{2}+|0-0|^{2}+|0-0|^{2}+|0-0|^{2}+ \\
|0-0|^{2}+|0-0|^{2}+|0-0|^{2}+|0-0|^{2}+|0-0|^{2}+|0-0|^{2}+ \\
|0-0|^{2}+|0-0|^{2}+|0-0|^{2}+|0-0|^{2}+|0-0|^{2}+|0-0|^{2}+ \\
|0-0|^{2}+|0-0|^{2}+|0-0|^{2}+|0-0|^{2}+|0-0|^{2}+|0-0|^{2}+ \\
|0-0|^{2}+|0-0|^{2}+|0-0|^{2}+|0-0|^{2}+|0-0|^{2}+|0-0|^{2}+ \\
|0-0|^{2}+|0-0|^{2}+|0-0|^{2}+|0-0|^{2}+|0-0|^{2}+|0-0|^{2}+ \\
|0-0|^{2}+|0-0|^{2}+|0-0|^{2}+|0-0|^{2}+|0-0|^{2}+|0,7-0|^{2}+ \\
|1-0|^{2}+|1-0|^{2}+|0-0|^{2}+|1-0|^{2}
\end{array}\right)
$$$$
\operatorname{jarak}_{(T 118, \mathrm{Tl})}=3,08
$$

- $\operatorname{Jarak}_{(\mathrm{T} 118, \mathrm{~T} 2)}$

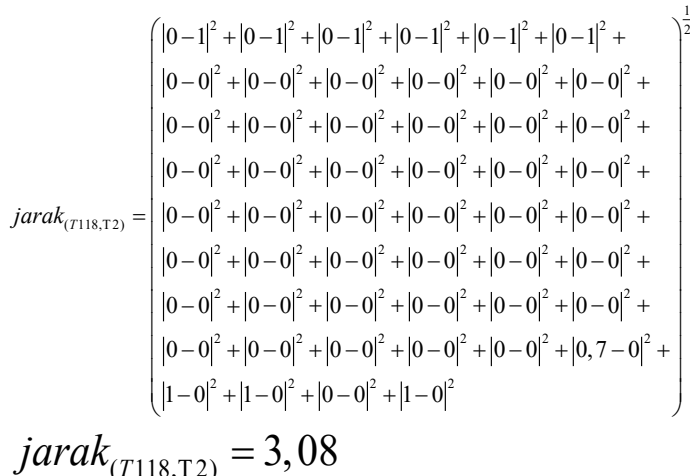

- $\operatorname{Jarak}_{(\mathrm{T} 118, \mathrm{~T} 3)}$

$$
\text { jarak }_{(T 11, T, T)}=\left(\begin{array}{l}
|0-1|^{2}+|0-1|^{2}+|0-1|^{2}+|0-1|^{2}+|0-1|^{2}+|0-1|^{2}+ \\
|0-0|^{2}+|0-0|^{2}+|0-0|^{2}+|0-0|^{2}+|0-0|^{2}+|0-0|^{2}+ \\
|0-0|^{2}+|0-0|^{2}+|0-0|^{2}+|0-0|^{2}+|0-0|^{2}+|0-0|^{2}+ \\
|0-0|^{2}+|0-0|^{2}+|0-0|^{2}+|0-0|^{2}+|0-0|^{2}+|0-0|^{2}+ \\
|0-0|^{2}+|0-0|^{2}+|0-0|^{2}+|0-0|^{2}+|0-0|^{2}+|0-0|^{2}+ \\
|0-0|^{2}+|0-0|^{2}+|0-0|^{2}+|0-0|^{2}+|0-0|^{2}+|0-0|^{2}+ \\
|0-0|^{2}+|0-0|^{2}+|0-0|^{2}+|0-0|^{2}+|0-0|^{2}+|0-0|^{2}+ \\
|0-0|^{2}+|0-0|^{2}+|0-0|^{2}+|0-0|^{2}+|0-0|^{2}+|0,7-0|^{2}+ \\
|1-0|^{2}+|1-0|^{2}+|0-0|^{2}+|1-0|^{2} \\
\operatorname{jarak}_{(T 118, T 3)}=3,08
\end{array}\right)
$$

Dan seterusnya sampai denganj $\operatorname{arak}_{(\mathrm{T} 118, \mathrm{~T} 96)}$. Hasilnya dapat dilihat pada Tabel 1 berikut:

Tabel 1.Jarak Data Ujidengan data latih.

\begin{tabular}{lrr}
\hline Jarak & Euclidian & \multicolumn{1}{c}{ Kelas } \\
\hline $\mathrm{T} 118, \mathrm{~T} 1$ & 3,08 & 1 \\
$\mathrm{~T} 118, \mathrm{~T} 2$ & 3,08 & 1 \\
$\mathrm{~T} 118, \mathrm{~T} 3$ & 3,08 & 1 \\
$\mathrm{~T} 118, \mathrm{~T} 4$ & 3,08 & 1 \\
$\mathrm{~T} 118, \mathrm{~T} 5$ & 3,08 & 1 \\
$\mathrm{~T} 118, \mathrm{~T} 6$ & 3,08 & 1 \\
$\mathrm{~T} 118, \mathrm{~T} 7$ & 3,08 & 1 \\
$\mathrm{~T} 118, \mathrm{~T} 8$ & 3,08 & 1 \\
$\mathrm{~T} 118, \mathrm{~T} 9$ & 2,91 & 2 \\
$\mathrm{~T} 118, \mathrm{~T} 10$ & 2,91 & 2 \\
$\mathrm{~T} 118, \mathrm{~T} 11$ & 2,91 & 2 \\
$\mathrm{~T} 118, \mathrm{~T} 12$ & 2,91 & 2 \\
$\mathrm{~T} 118, \mathrm{~T} 13$ & 2,91 & 2 \\
$\mathrm{~T} 118, \mathrm{~T} 14$ & 2,91 & 2 \\
$\mathrm{~T} 118, \mathrm{~T} 15$ & 2,91 & 2 \\
$\mathrm{~T} 118, \mathrm{~T} 16$ & 2,91 & 2 \\
$\mathrm{~T} 118, \mathrm{~T} 96$ & 1,45 & 12 \\
\hline
\end{tabular}

Langkah kedua:

Mengurutkan nilai hasil perhitungan jarak Euclidean mulai dari nilai terkecil ke nilai yang terbesar sebanyak $k$ (ketetanggan) data 
terdekat. Digunakan $k=9$ maka hasilnya ditunjukkan pada Tabel 2 berikut.

Tabel 2. Data yang diurutkan sebanyak $\mathrm{K}=9$

\begin{tabular}{ccc} 
Nilai & Jarak & Kelas \\
\hline $\mathbf{1 , 4 5}$ & T118,T89 & 12 \\
$\mathbf{1 , 4 5}$ & T118,T90 & 12 \\
$\mathbf{1 , 4 5}$ & T118,T91 & 12 \\
$\mathbf{1 , 4 5}$ & T118,T92 & 12 \\
$\mathbf{1 , 4 5}$ & T118,T93 & 12 \\
$\mathbf{1 , 4 5}$ & T118,T94 & 12 \\
$\mathbf{1 , 4 5}$ & T118,T95 & 12 \\
$\mathbf{1 , 4 5}$ & T118,T96 & 12 \\
$\mathbf{2 , 3 4}$ & T118,T25 & 4 \\
\hline
\end{tabular}

Langkah keempat:

Menentukan nilai keanggotaan data terhadap setiap kelas. Jika data memiliki kelas yang sama maka bernilai 1 dan jika berbeda bernilai 0 .

- Nilai keanggotaan setiap data $k$ terhadap Kelas 1 ditunjukkan pada Tabel 3

Tabel3. Data bobot pada Kelas 12

\begin{tabular}{ccc} 
Nilai & Jarak & Kelas \\
\hline $\mathbf{1 , 4 5}$ & T118,T89 & 1 \\
$\mathbf{1 , 4 5}$ & T118,T90 & 1 \\
$\mathbf{1 , 4 5}$ & T118,T91 & 1 \\
$\mathbf{1 , 4 5}$ & T118,T92 & 1 \\
$\mathbf{1 , 4 5}$ & T118,T93 & 1 \\
$\mathbf{1 , 4 5}$ & T118,T94 & 1 \\
$\mathbf{1 , 4 5}$ & T118,T95 & 1 \\
$\mathbf{1 , 4 5}$ & T118,T96 & 1 \\
$\mathbf{2 , 3 4}$ & T118,T25 & 0 \\
\hline Nilai keanggotaan setiap data $k$ \\
terhadap Kelas 4 ditunjukkan pada \\
Tabel 4.
\end{tabular}

Tabel 4. Data bobot pada Kelas 10

\begin{tabular}{ccc} 
Nilai & Jarak & Kelas \\
\hline $\mathbf{1 , 4 5}$ & T118,T89 & 0 \\
$\mathbf{1 , 4 5}$ & T118,T90 & 0 \\
$\mathbf{1 , 4 5}$ & T118,T91 & 0 \\
$\mathbf{1 , 4 5}$ & T118,T92 & 0 \\
$\mathbf{1 , 4 5}$ & T118,T93 & 0 \\
$\mathbf{1 , 4 5}$ & T118,T94 & 0 \\
$\mathbf{1 , 4 5}$ & T118,T95 & 0 \\
$\mathbf{1 , 4 5}$ & T118,T96 & 0 \\
$\mathbf{2 , 3 4}$ & T118,T25 & 1 \\
\hline
\end{tabular}

Langkah kelima:

Menentukan nilai keanggotaan setiap kelas dengan menggunakan persamaan 2.2.

- Perhitungan nilai keanggotaan Kelas 12 sebagai berikut:

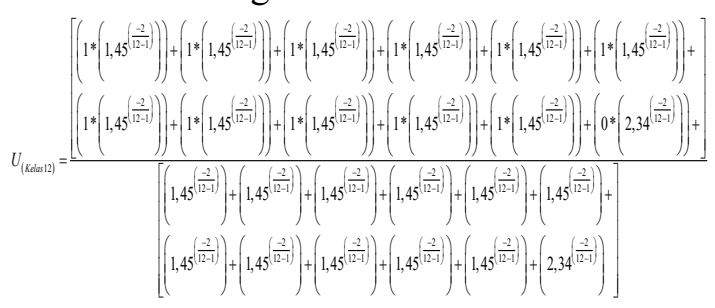

$U_{(\text {Sdirar } 12)}=0,89$

- Perhitungan nilai keanggotaan Kelas 4 sebagai berikut:

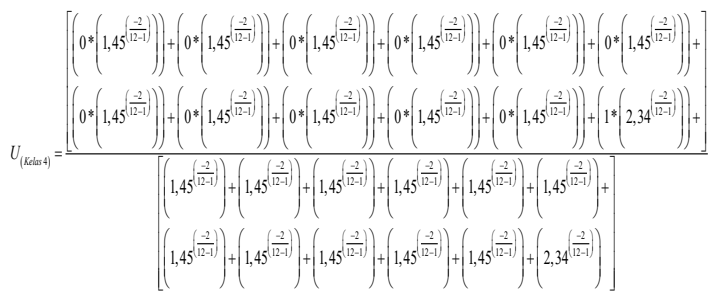

$U_{(\text {Kelast })}=0,11$

Pada perhitungan manual nilai keanggotaan Kelas 12 memiliki nilai keanggotaan yang terbesar yaitu 0,89. Sehingga hewan ternak tersebut menderita penyakit Rabies.

\section{Perhitungan dengan Program}

Untuk kasus yang sama juga dilakukan perhitungan dengan program yang di bangun langkah-langkah sebagai berikut:

Langkah 1 Melakukan Input Gejala ditunjukan melaui Gambar 9 berikut:

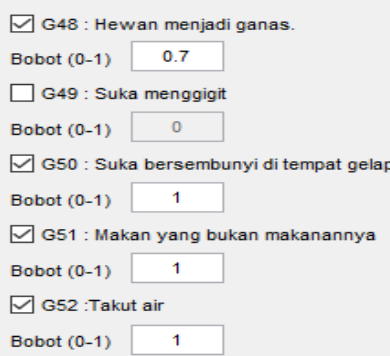

Gambar9. Input Gejala

Langkah 2 Menyimpan gejala yang sudah diinputkan ke dalam program untuk dilakukan proses perhitungan ditunjukan melaui Gambar10 berikut:

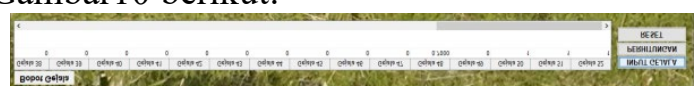

Gambar8.Menyimpan gejala dalam Program Gejala 
Langkah 3 melakukan proses

perhitunganditunjukanmelauigambar 9berikut:

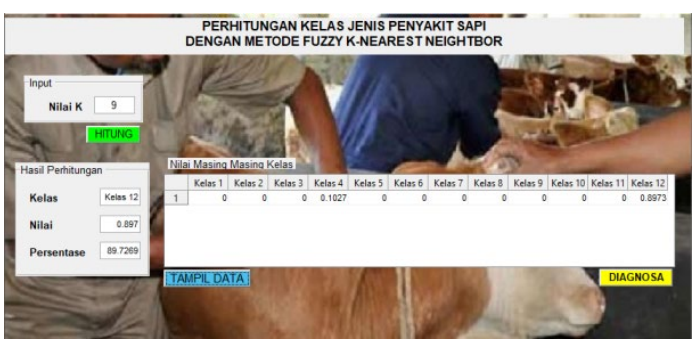

Gambar10.Melakukan Proses perhitungan

Langkah 4

menampilkandiagnosahasilperhitunganmelalui Gambar11berikut:

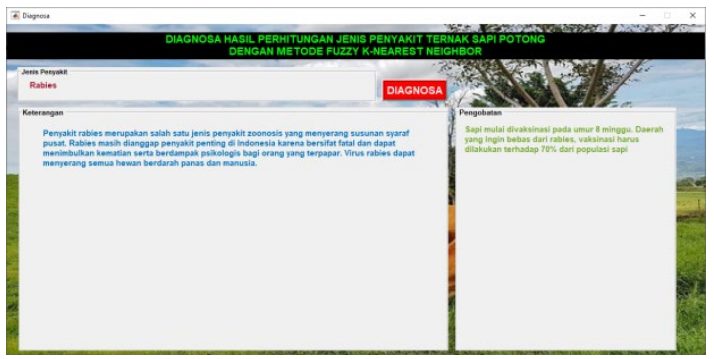

Gambar11Diagnosahasilperhitungan.

Berdasarkan kedua hasil perhitungan baik perhitungan manual maupun perhitungan dengan program memiliki hasil yang sama yaitu Penyakit Rabies dengan bobot 0,897 atau $89,7 \%$

b. Pengujian Sistem

Pengujian dilakukan untuk mengetahui seberapa besar akurasi Fuzzy K-Nearest Neighbor dalam mengklasifikasi kelas. Nilai K yang digunakan adalah 9 dengan 67 sampel data. Pengujian menggunakan confusion matrix untuk mencari tingkat akurasi dan laju error. Sedangkan holdout digunakan untuk membagi data latih dan data uji dengan nilai perbandingan 5:1 data latih dengan data uji. Pengujian dilakukan sebanyak 10 kali pengujian. Berikut hasil pengujian yang dilakukan:

Tabel 5. Akurasi dan Laju error

\begin{tabular}{llll}
\hline No & Pengujian & Akurasi & LajuError \\
\hline 1 & Pengujian 1 & $75 \%$ & $25 \%$ \\
2 & Pengujian 2 & $91,6 \%$ & $8,3 \%$ \\
3 & Pengujian 3 & $100 \%$ & $0 \%$ \\
4 & Pengujian 4 & $91,6 \%$ & $8,3 \%$ \\
5 & Pengujian 5 & $100 \%$ & $0 \%$ \\
6 & Pengujian 6 & $83,3 \%$ & $16,6 \%$ \\
7 & Pengujian 7 & $91,6 \%$ & $8,3 \%$ \\
8 & Pengujian 8 & $91,6 \%$ & $8,3 \%$ \\
\hline
\end{tabular}

\begin{tabular}{llll}
\hline No & Pengujian & Akurasi & LajuError \\
\hline 9 & Pengujian 9 & $91,6 \%$ & $8,3 \%$ \\
10 & Pengujian 10 & $100 \%$ & $0 \%$ \\
& Rata-rata & $93,8 \%$ & $6,2 \%$ \\
\hline
\end{tabular}

Gambar 4.10 menunjukkan akurasi dan laju error dalam bentuk grafik.

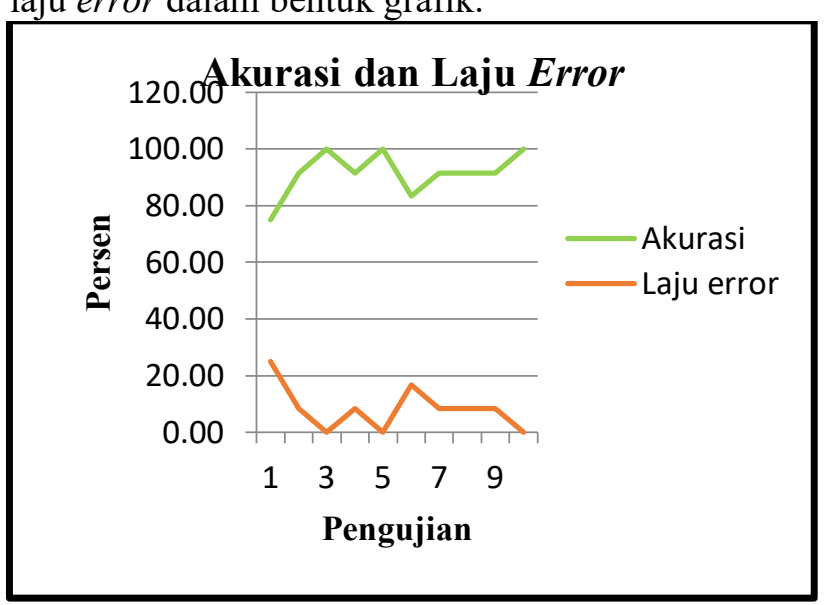

Gambar 12.Grafik Akurasi dan Laju Error pengujian

\section{KESIMPULAN}

Berdasarkan hasil dan pembahasan pada bab sebelumnya maka penulis dapat mengambil beberapa kesimpulan yaituMetode Fuzzy K-NearestNeighbor dapat menentukan jenis penyakit secara tepat dengan mendapatkan nilai $\mathrm{K}$ terbaik. Nilai $\mathrm{K}$ yang digunakandalam penelitian ini yaitu 9 dengan rata- rata persentase akurasi sebesar 93,8 \% danlajuerror $6,2 \%$.

\section{UCAPAN TERIMA KASIH}

Terima kasih penulis ucapkan kepada Bapak Yohanes Suban Belutowe dan Bapak Yohanis Malelak selaku Pembimbing, ucapan terima kasih Kepala Bagian Dinas Peternakan Kabupaten Kupang, yang telah membantu selama pengumpulan data.

\section{DAFTAR PUSTAKA}

[1] Astiti, L.G.S, 2010. Petunjuk Praktis Manajemen Pencegahan dan Pengendalian Penyakit pada Ternak Sapi. Nusa Tenggara Barat. Balai Pengkajian Teknologi Pertanian NTB. 
[2] E.Akbas. 2008. FuzzyKnearestneighborsclassifierthatwaspropose dby J. M. Keller et.al.https://www.mathworks.com/matlabc entral/fileexchange/ 21326-fuzzy-knn.2008; 2019 Mei 19.

[3] Hamdan A, Rohaeni S.E. 2010. Budidaya Sapi Potong. Kalimantan Selatan. Balai Pengkajian Teknologi Pertanian Kalimantan Selatan.

[4] KementerianPertanianDirektoratJenderalP eternakandanKesehatanHewanDirektorat KesehatanHewan. 2014. Manual PenyakitHewanMamalia.

[5] Kurnianingtyas Diva, Rahardian B.A., Mahardika D.P., Kartika A., dan Angraeni Dwi. 2017. Sistem Pendukung Keputusan Diagnosis Penyakit Sapi Potong Menggunakan K- NearestNeighbour (K$\mathrm{NN}$ ). Jurnal Teknologi Informasi dan Ilmu Komputer (JTIIK).Vol. 4. No. 2, Juni 2017.Hlm. 122-126.

[6] Nugraha S.D., Putri R.R.M., dan Wihandika R.C. 2017. Penerapan Fuzzy K-Nearest Neighbor (FK-NN) Dalam Menentukan Status Gizi Balita.Jurnal Pengembangan Teknologi Informasi dan Ilmu Komputer. Vol. 1. No. 9, Juni 2017.Hlm. 925-932.

[7] Ompusunggu E.A., Ratnawati D.E., dan MuflikhahLailil. 2017. Identifikasi Penyakit Tanaman Jarak Pagar Menggunakan Metode Fuzzy K-Nearest Neighbor (FK-NN). Jurnal Pengembangan Teknologi Informasi dan Ilmu Komputer. Vol. 1. No. 5, Mei 2017.Hlm. 368-377.

[8] Prasetyo, Eko. 2012. Data Mining Konsep dan Aplikasi menggunakan matlab. Yogyakarta: Andi.

[9] Priyanto Dwi. 2016. Strategi Pengembalian wilayah Nusa Tenggara Timur Sebagai Sumber Ternak Sapi Potong. Jurnal Litbang Pertanian. Vol. 35. No. 4 Desember 2016. Hlm. 167-178.

[10] Rialdi B.R, Hidayat N, Suprapto. 2018. Identifikasi Penyakit Pada Kambing Menggunakan Metode Fuzzy KNearestNeighbor (F-KNN). Jurnal Pengembangan Teknologi Informasi dan Ilmu Komputer. Vol. 2. No. 10, Oktober 2018. Hlm. 4312-4317

[11] Tjahajati Ida,Gunanti, Suwarno, Sutisna
Abadi, Widjajanti Sri, dan Raharjo Enuh. 2014.Manual Penyakit Hewan Mamalia. Direktorat Jenderal Peternakan dan Kesehatan Hewan Kementerian Pertanian.

[12] Tyas R.D.O, Soebroto A.A, Furqon M. Tanzil. 2015. Pengembangan Sistem Pakar Diagnosa Penyakit Sapi Potong Dengan Metode Fuzzy K-Nearest Neighbour. Journal of Environmental Engineering \& Sustainable Technology. Vol. 02 No. 01, Juli 2015, Hlm. 58-66 